\title{
Hepatic response to increased exogenous supply of plasma amino acids by infusion into the mesenteric vein of Holstein- Friesian cows in late gestation
}

\author{
BY D. WRAY-CAHEN ${ }^{1 *}$, J. A. METCALF ${ }^{1} \dagger$, F. R. C. BACKWELL ${ }^{2}$, B. J. BEQUETTE ${ }^{2}$,
} D. S. BROWN ${ }^{2}$, J. D. SUTTON ${ }^{1}$ AND G. E. LOBLEY ${ }^{2} \ddagger$

${ }^{1}$ AFRC IGER, Hurley, Maidenhead SL6 5LR

${ }^{2}$ Rowett Research Institute, Bucksburn, Aberdeen AB21 9SB

(Received 14 November 1996 - Revised 30 May 1997 - Accepted 6 June 1997)

\begin{abstract}
The hepatic responses of late gestation, dry dairy cows to acute $(6 \mathrm{~h})$ infusions of an amino acid (AA) mixture (Synthamin; 0.0, 1.1, 2.2, 4.4, 8.8 and $17.6 \mathrm{mmol} / \mathrm{min}$ ) into the mesenteric vein were determined. Neither blood flow nor $\mathrm{O}_{2}$ consumption across the portal-drained viscera (PDV) and liver was significantly altered by infusion. Similarly, there were no effects on net absorption, or hepatic removal, of acetate, propionate, butyrate or $\mathrm{NH}_{3}$. Glucose PDV appearance was unchanged but hepatic glucose production increased $(P=0.032) \mathrm{by} 0.2 \mathrm{mmol} / \mathrm{min}$ per $\mathrm{mmol} / \mathrm{min}$ of $A A$ infused. Additional extraction of alanine, glycine (both infused) and glutamine (not infused) by the liver was sufficient to account for most of the extra $C$ required for glucose synthesis. The $N$ that would be liberated from these glucogenic AA would also account for a large proportion of the increase in urea- $\mathrm{N}$ produced in response to the $\mathrm{AA}$ infusion. This supports the concept of a correlation between gluconeogenesis and ureagenesis. Furthermore, the amide- $\mathrm{N}$ liberated from the extracted glutamine would contribute up to 0.17 of hepatic $\mathrm{NH}_{3}$ fux and assist in balancing $\mathrm{N}$ inputs into the carbamoyl phosphate and arginosuccinate entry points of the ornithine cycle. Rates of fractional extraction of the various AA by the liver were best fitted by linear equations, indicating that even at the highest rates of administration (approximately twice maximal physiological absorption) the transport systems were not saturated. Hepatic fractional extractions of infused essential AA were highest for methionine (0.83) and phenylalanine (0.87) with the lowest proportion removed observed for valine $(0.25)$, leucine (0.30), lysine (0.31) and isoleucine (0.49). For the non-essential AA, the highest apparent fractional extractions were for glycine (0.73), arginine (0.79) and tyrosine (0.63) followed by alanine (0.54), proline (0.47) and serine (0.37). Hepatic removal of AA-N exceeded the increase in urea-N formation such that, at the highest rate of infusion, approximately $10 \mathrm{mmol} / \mathrm{min}$ of the extracted AA was apparently available for hepatic anabolism, more than is required to account for assumed increases in liver mass and export protein synthesis. Similarly, the amount of AA available for peripheral tissue protein gain, when assessed against phenylalanine supply as the limitation, would be the equivalent of a maximum of $0.5 \mathrm{~g}$ protein retained/min $(6 \mathrm{mmol} \mathrm{AA}-\mathrm{N} / \mathrm{min})$. This would provide sufficient AA for replenishment of peripheral (muscle) protein stores plus support of the placenta and fetus.
\end{abstract}

Amino acids: Urea: Liver: Cattle

Only a small proportion of the total amino acids (AA) absorbed from the small intestine into the hepatic portal vein reaches the peripheral circulation in free form because

* Present address: USDA, Beltsville, MD 20705, USA.

$\uparrow$ Present address: ADAS Bridgets, Winchester SO21 1AP.

$\ddagger$ For reprints. 
substantial amounts are removed by the liver (e.g. Wolff et al. 1972; Rérat et al. 1992; Lobley et al. 1995, 1996). The proportion which the liver extracts varies between AA and, although probably influenced by several factors, including nutrition, there are some general trends which are exhibited across species. These include a greater proportion of glycine, alanine and the aromatic AA removed by the liver compared with the branchedchain amino acids (BCAA). In ruminants, although removal of non-essential AA may provide substrates for synthesis of other metabolites, notably glucose (Bergman, 1973), complete removal of essential AA (e.g. histidine and phenylalanine; Wolff et al. 1972) may leave inadequate quantities of these to support peripheral tissue gain. Unfortunately, the data available on hepatic transfers of individual AA are limited and often restricted to animals maintained either below or close to $\mathrm{N}$ equilibrium (Elwyn et al. 1972; Wolff et al. 1972; Lobley et al. 1995) where peripheral tissue net requirements may be small. Under these circumstances, AA catabolism, with urea of hepatic origin as the major end product, will balance with net absorption and equal the endogenous losses. Thus, the absorption : hepatic extraction ratio will, of necessity, approach unity. For growing, lactating, or pregnant animals extra amino acids must be available beyond the liver, but exactly how this supply is regulated is unclear. For example, the amino acids available to the periphery may be a simple consequence of supply exceeding the ability of the liver to metabolize AA. Such limitations may involve saturation of AA transporters, restricted oxidative (ureagenic) capacity or maximization of anabolic synthesis of hepatic constitutive and export proteins. Some, or all, of these systems may be regulated by nutrient-hormone interactions, possibly involving signals transmitted between anabolic peripheral tissues and the liver.

Such mechanisms are difficult to unravel in vivo but the capacity of the liver to extract and metabolize AA can be examined by graded additions of AA, within the physiological range, in situations where the net requirements of the peripheral tissues are limited. In the current study, this was investigated using pregnant, dry dairy cows. The acute responses $(6 \mathrm{~h})$ of these cows to intra-mesenteric-vein infusions of six levels of a commercial parenteral AA mixture were examined by use of a hepatic arterio-venous preparation.

\section{MATERIALS AND METHODS}

\section{Animals and diet}

Three multiparous, lactating Holstein-Friesian cows, at 6 months of gestation were prepared surgically with mesenteric (2), hepatic-portal, hepatic vein and mesenteric artery catheters as described by Huntington et al. (1989). A carotid artery was elevated subcutaneously at the same time, to provide, if required, an alternative source of arterial blood; in the event, the excellent catheter patency made this precaution unnecessary. Following surgery, the animals were allowed to cease milk production. Catheter patency was maintained by flushing with sterile physiological saline $(8.9 \mathrm{~g} \mathrm{NaCl} / \mathrm{l})$ containing heparin $(250 \mathrm{IU} / \mathrm{ml})$ every $21 \mathrm{~d}$. The portal-drained viscera (PDV) preparation included the combined venous drainage from the reticulo-rumen, abomasum, small and large intestines plus the pancreas. The hepatic vein catheter drained one lobe of the liver, which was assumed to have similar metabolism to the other lobes; values reported are for the total liver. The splanchnic measurements represent the combined metabolism across the PDV and liver.

Animals were fed on a diet of grass silage $(8 \mathrm{~kg} \mathrm{DM} / \mathrm{d})$ and rolled barley $(2 \mathrm{~kg} \mathrm{DM} / \mathrm{d})$. The daily ration was divided into twelve equal portions and offered every $2 \mathrm{~h}$ by means of 
automated feeders. The diet was calculated to provide daily $1230 \mathrm{~g}$ crude protein $(\mathrm{N} \times 6 \cdot 25)$ and $105 \mathrm{MJ}$ metabolizable energy. Cows were adjusted to the diet 3 weeks before the experimental protocol and to the frequent feeding regimen for $7 \mathrm{~d}$ before the study. Any refusals were recorded daily.

\section{Experimental design and protocol}

In the last month of gestation each cow received six separate levels of an AA mixture (Synthamin 17, Baxter Healthcare Ltd, Thetford, Norfolk) to provide either 0, 1.1, 2.2, 4.4, 8.8 or $17.6 \mathrm{mmol} \mathrm{AA} / \mathrm{min}$ infused into the mesenteric vein (the highest rate of infusion was the equivalent of $24 \mathrm{mmol} \mathrm{AA}-\mathrm{N} / \mathrm{min}$ ). The composition of the most concentrated infusate (mmol/1) was: alanine 207 , arginine 59 , glycine 122 , histidine 28 , isoleucine 41 , leucine 50 , lysine 28 , methionine 24 , phenylalanine 30 , proline 53 , serine 43 , threonine 31 , tryptophan 8 , tyrosine 1.8 , and valine 43 (total $769 \mathrm{mmol} / 1$ ). Each infusion lasted for $6 \mathrm{~h}$ and was preceded by a $3.5 \mathrm{~h}$ period during which physiological saline was infused and blood samples were taken for covariate analyses. For each animal at least $38 \mathrm{~h}$ were left between consecutive infusions and no more than three infusions were performed in any $7 \mathrm{~d}$ period. The same rate of fluid infusion $(22.9 \mathrm{ml} / \mathrm{min})$ was maintained by appropriate dilution with physiological saline. During the covariate infusion period and the last $3.5 \mathrm{~h}$ of AA infusion period sodium $p$-amino hippurate ( $\mathrm{pAH} ; 0.107 \mathrm{~g}$ infused $/ \mathrm{min}$ ) was added to the infusate so that splanchnic bed plasma flows could be quantified. The order of infusions for the three animals was an incomplete randomization of the $0,4.4,8.8$ and $17.6 \mathrm{mmol} / \mathrm{min}$ rates, with the 1.1 and $2.2 \mathrm{mmol} / \mathrm{min}$ as the last two infusions.

\section{Blood collection and analyses}

Blood samples $(17 \mathrm{ml})$ were withdrawn simultaneously into heparinized syringes from the artery plus hepatic portal and hepatic veins at $30 \mathrm{~min}$ intervals during the last $2.5 \mathrm{~h}$ of each infusion period. One portion was frozen as whole blood $\left(-20^{\circ}\right)$ and the remainder was centrifuged at $1000 \mathrm{~g}$ at $4^{\circ}$ for $20 \mathrm{~min}$. The plasma obtained was divided into several portions and either stored frozen or kept at $4^{\circ}$ for analysis on the same day of $\mathrm{pAH}$, urea, and $\mathrm{NH}_{3}$ on a Cobas Mira Analyser (Hoffman-La Roche, Switzerland) as described previously (Metcalf et al. 1994). A further $1 \mathrm{ml}$ blood sample was taken under anaerobic conditions, stored on ice and within $1 \mathrm{~h}$ the $\mathrm{pO}_{2}$ was measured (IL 1306 Blood Gas Analyser, Instrument Laboratory Spa, Milan, Italy). This sub-sample was then stored at $-20^{\circ}$ until haemoglobin $(\mathrm{g} / \mathrm{l})$ was determined by a Haemoglobin Test Combination kit (Boehringer Mannheim Ltd, Lewes, Sussex). Packed cell volume (PCV) was determined by haematocrit.

Plasma samples were thawed at $4^{\circ}$ and analysed, by enzymic procedures, for glucose, 2-hydroxybutyrate and lactate on a Cobas Mira Analyser (Hoffman-La Roche) as described previously (Metcalf et al. 1994). During the last $2 \mathrm{~h}$ of either the covariate or infusion period equal amounts of blood or plasma samples were combined to yield composite samples for analysis. Plasma concentrations of insulin (Tindall et al. 1978), insulin-like growth factor-1 (IGF-1) (Brier et al. 1991) and cortisol (Symonds et al. 1986) were determined on arterial samples. Volatile fatty acids (VFA) were analysed as described by Seal et al. (1992). Plasma ( $1 \mathrm{~g}$ ) was mixed with 0.15 by weight of a $1 \mathrm{mM}-\mathrm{L}-$ norleucine solution and then 0.15 by volume of $480 \mathrm{~g} / 1$ sulfosalicylic acid added. The supernatant fraction obtained by centrifugation at $13500 \mathrm{~g}$ for $10 \mathrm{~min}$ was further clarified through microcentrifuge filters (Sigma Chemical Co., Poole, Dorset) and then $100 \mathrm{~g} / \mathrm{NaOH}$ 
(normally $50 \mu \mathrm{l}$ ) added to yield $\mathrm{pH} \mathrm{2-3.} \mathrm{This} \mathrm{latter} \mathrm{step} \mathrm{improved} \mathrm{separation} \mathrm{in} \mathrm{the} \mathrm{acidic}$ region during the subsequent ion-exchange-based analysis on an Alpha Plus Amino Acid Analyser (Pharmacia LKB, Uppsala, Sweden) equipped with a ninhydrin detection system and using buffer combinations appropriate for physiological fluids.

\section{Calculations}

The blood $\mathrm{O}_{2}$ content $(\mathrm{mmol} / \mathrm{l})$ was calculated from

$$
0.446 \times 1.34 \times \mathrm{Hb} \times\left(\% \text { saturation } \mathrm{O}_{2}\right) / 100,
$$

where $\mathrm{Hb}$ is haemoglobin concentration $(\mathrm{g} / 100 \mathrm{ml}), 1.34$ is $\mathrm{O}_{2}$ binding at complete $\mathrm{Hb}$ saturation $(\mathrm{ml} / 100 \mathrm{~g})$ and \% saturation $\mathrm{O}_{2}$ (Sigaard-Anderson, 1974) equals

$$
100 \times\left(\mathrm{pO}_{2} / 34 \cdot 1\right)^{2 \cdot 68} /\left(1+\left(\mathrm{pO}_{2} / 34 \cdot 1\right)^{2 \cdot 68}\right) \text {. }
$$

Plasma flows were calculated as described by Huntington et al. (1989) and corresponding blood flows were derived based on the appropriate PCV data. PDV, hepatic and splanchnic transfers ( $\mathrm{mmol} / \mathrm{min}$ ) of plasma metabolites were calculated as follows:

$$
\begin{aligned}
\text { PDV appearance (PA) } & =\left(M_{p}-M_{a}\right) \times F_{p}, \\
\text { hepatic removal }(H R) & =\left(\left(M_{h}-M_{p}\right) \times F_{p}\right)+\left(\left(M_{h}-M_{a}\right) \times F_{a}\right), \\
\text { splanchnic transfers } & =\left(M_{h}-M_{a}\right) \times F_{h}, \\
\text { hepatic inflow (HI) } & =\left(M_{p} \times F_{p}\right)+\left(M_{a} \times F_{a}\right),
\end{aligned}
$$

net $\mathrm{PA}=\mathrm{PA}$ under infusion conditions $-\mathrm{PA}$ under basal, pre-infusion conditions,

net $\mathrm{HI}=\mathrm{HI}$ under infusion conditions $-\mathrm{HI}$ under basal, pre-infusion conditions,

where $\mathbf{M}$ is metabolite concentration ( $\mathrm{mmol} / \mathrm{l}$ ), $\mathbf{F}$ represents plasma flow (litres/min) and the subscripts ' $a$ ', 'p' and ' $h$ ' refer to arterial, hepatic portal and hepatic venous samples. Positive values indicate net production across the tissues and negative values net uptake.

\section{Statistical procedures}

Variables that were not deliberately varied by the experimental design (i.e. all measurements except those relating to AA concentrations and transfers) were compared by one-way ANOVA with animals as blocks and levels of AA infusion as treatment (Genstat for Windows Release 3.2, 1996; Lawes Agricultural Trust, IACR-Rothamsted, Harpenden, Herts.). The net mass transfers of individual AA across the PDV for each cow and infusion rate were corrected for the pre-infusion covariate value (i.e. to yield the appearance above the 'basal' rate which was due to diet alone) and the combined data for all animals analysed as the dependent value against the corresponding rate of infusion (independent variable) using regression analyses for linear and quadratic constraints (Genstat for Windows Release 3.2). Hepatic transfers of each AA were analysed by similar regression approaches, with removal across the liver as the dependent variable $v$. the increased net inflow to the liver above that observed for the covariate period. For AA which were not in the infusate the average appearance and removal were calculated. For a variety of reasons, mainly of a technical nature, a small number of individual measurements (two or less from a total of eighteen possible) were identified as outliers for each AA and eliminated from the data sets for statistical analysis. 


\section{RESULTS}

All infusions and collections were successfully completed and there were no refusals on the days of infusion except the last infusion $(2.2 \mathrm{mmol} / \mathrm{min})$ for one animal. Data for this infusion were removed from the analysis. Furthermore, blood flows, arterial AA concentrations and PDV uptakes of metabolites were not significantly different between any of the pre-infusion periods, indicative of a rapid return to basal conditions and with no detectable carry-over effects. Hepatic and hepatic portal venous blood flows were not significantly different between the various levels of AA infusion (Table 1). Calculated hepatic artery inflow contributed, on average, $0 \cdot 1$ (range $0.02-0 \cdot 17$ ) to hepatic venous flow. Plasma flow represented 0.72 of corresponding blood flows.

\section{Non-amino acid metabolite transfers}

Although there was net production of glucose across the splanchnic tissues (Table 1) the PDV was a net consumer, accounting for the equivalent of 0.14 (range 0.02-0.25) of hepatic output. Hepatic $(P<0.05)$ and splanchnic $(P<0 \cdot 10)$ output of glucose increased at the higher rates of AA infusion rate although the PDV extraction remained unchanged. In contrast, lactate removal by the hepatic tissues was unaltered by AA infusion (mean $1.4 \mathrm{mmol} / \mathrm{min})$ while PDV appearance $(1.2 \mathrm{mmol} / \mathrm{min})$ was approximately 0.6 the $\mathrm{C}$ balance of glucose disappearance (results not shown). There was net absorption of $\mathrm{NH}_{3}$ across the PDV but all of this, plus a proportion of that supplied via the hepatic artery, was removed by the liver (Table 1). There were no significant effects either on PDV appearance, hepatic clearance or splanchnic uptake of $\mathrm{NH}_{3}$ as the rate of AA infusion increased. In the case of urea, net uptake by the PDV accounted for 0.81 (range 0.72-0.91) of liver production (Table 1). Although PDV urea uptake was unaltered by increased AA provision, hepatic ureagenesis was significantly elevated $(P<0.01$; Table 1$)$ at the higher infusion rates of AA, as was net splanchnic infusion $(P<0.02)$, compared with preinfusion values.

Transfers of VFA across the PDV and liver were not influenced by rate of AA infusion and the data across all treatments were therefore combined (Table 2). There was net production of acetate and 2-hydroxybutyrate by the liver under all circumstances while hepatic extractions of propionate, isobutyrate and butyrate were $0.87,1.02$ and 0.79 of net PDV appearance (Table 2). $\mathrm{O}_{2}$ consumptions across the PDV and liver were of similar magnitude but not influenced by the rate of AA infusion (Table 2).

The AA infusions in this study did not alter insulin-like growth factor-1 or cortisol concentrations (results not shown). However, plasma arterial insulin concentrations did increase (from 0.6 to $3 \mu \mathrm{g} / \mathrm{l}$ ) with increasing AA infusion rate $(\mathrm{mmol} / \mathrm{min}$ ). The linear equation describing this response was:

$$
\text { insulin concentration }=0.58+(0.13 \times \mathrm{AA} \text { infusion rate }), r^{2} 0.91 \text {. }
$$

\section{Amino acid transfers}

The results from the plasma exchanges of individual AA are presented in Tables 3 and 4 . Although a reasonable number of data points (up to eighteen) were available for the regression analyses the variance associated with such arterio-venous information meant that for some AA both linear or quadratic equations were significant but, in all cases, the linear regressions for PDV appearance were superior. 


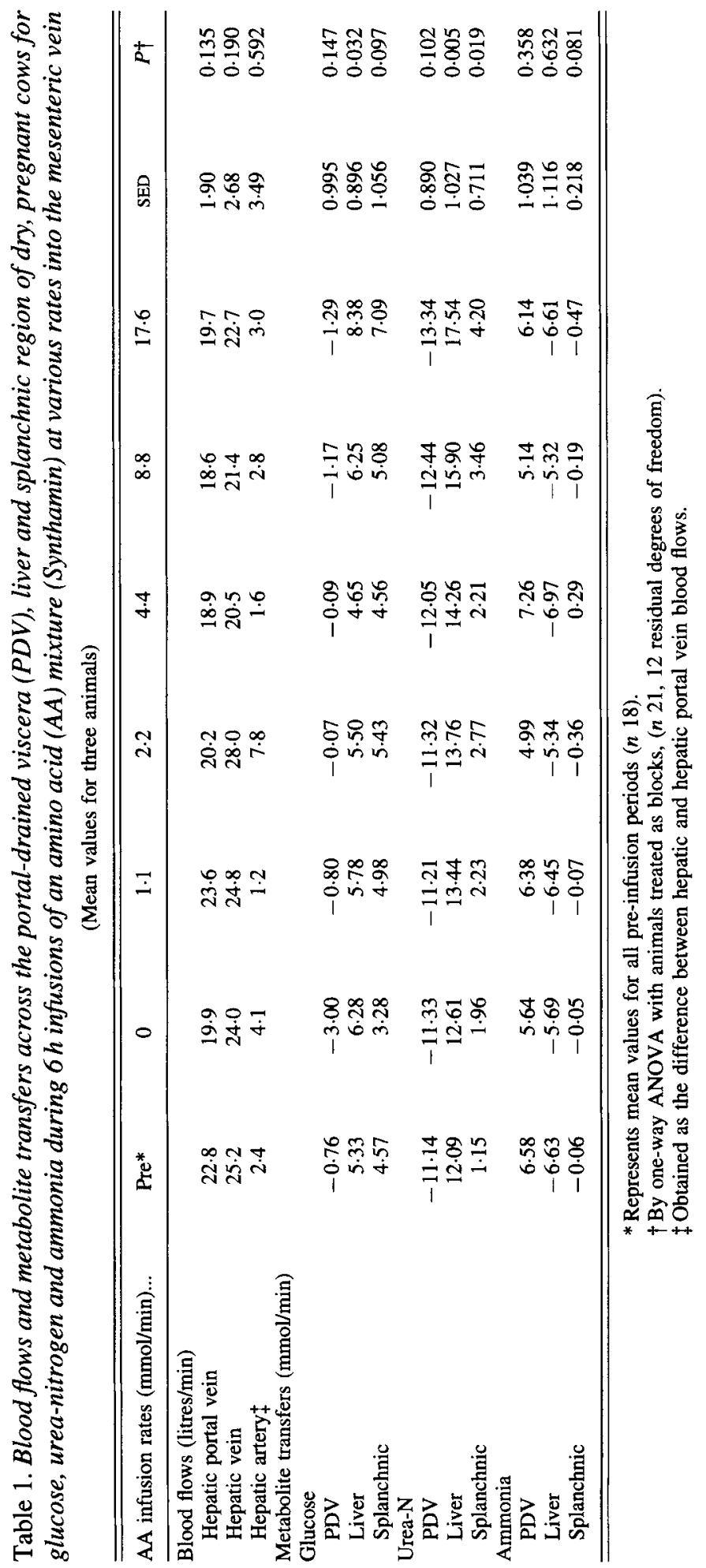


Table 2. Transfers across the portal-drained viscera (PDV) and liver of dry pregnant cows for volatile fatty acids and oxygen during $6 \mathrm{~h}$ infusions of an amino acid (AA) mixture (Synthamin) at different rates $(0,1.1,2.2,4.4,8.8$ and $17.6 \mathrm{mmol} / \mathrm{min})$ into the mesenteric vein

(Mean values and standard deviations for eighteen observations.)

\begin{tabular}{lcccc}
\hline \hline & \multicolumn{3}{c}{ Transfers (mmol/min) } \\
\cline { 2 - 5 } & \multicolumn{2}{c}{ PDV* } & \multicolumn{2}{c}{ Liver* } \\
\cline { 2 - 5 } & Mean & SD & Mean & SD \\
\hline Acetate & 17.30 & 1.47 & 4.22 & 1.98 \\
Propionate & 6.03 & 0.66 & -5.22 & 0.67 \\
Isobutyrate & 0.30 & 0.03 & -0.30 & 0.03 \\
n-Butyrate & 1.45 & 0.19 & -1.14 & 0.19 \\
2-Hydroxybutyrate & 2.28 & 0.37 & 2.48 & 0.54 \\
Oxygen & 32.7 & 1.87 & 31.4 & 4.91 \\
\hline \hline
\end{tabular}

*As there were no significant effects between the levels of AA infusions (nor against the pre-infusion values) all the data are combined $(n$ 18).

Portal-drained viscera appearance. For the non-essential AA (NEAA, Table 3) there were large PDV appearances of alanine, glycine, arginine and proline during the preinfusion period while glutamate and glutamine showed net removal by the gastrointestinal tissues. There was net absorption of all the essential AA (EAA, Table 4) under basal conditions. Under the basal dietary conditions net appearance of AA-N in plasma across the PDV amounted to $3.29 \mathrm{mmol} / \mathrm{min}$, equivalent to $66 \mathrm{~g} \mathrm{~N} / \mathrm{d}$. This represented $34 \%$ of dietary $\mathrm{N}$ intake compared with $63 \%$ absorbed as $\mathrm{NH}_{3}$ (without correction for urea- $\mathrm{N}$ recycled to the digestive tract).

During the pre-infusion periods the relative amounts of the absorbed EAA can be compared with their proportions in rumen microbial protein. If the molar proportion of phenylalanine either absorbed or present in rumen microbial protein is used as a relative basis then the appearance of absorbed AA compared with that expected from microbial sources was histidine 1.40 , isoleucine 1.05 , leucine 1.28 , lysine 0.83 , methionine 0.90 , threonine 0.79 , valine 1.03 . If the agreement were perfect all the values would equal unity so a reasonable match was obtained for isoleucine, valine, methionine and, of course, phenylalanine.

During infusion of the AA the recoveries of alanine, isoleucine, methionine and threonine in the portal venous plasma, after subtraction of the appropriate pre-infusion PDV appearance, were close to the increment administered. Recoveries greater than theoretical were observed for glycine, proline and valine. Data for the latter two AA are compromised by the presence of co-eluting or overlapping peaks during chromatography. For certain AA, notably the basic lysine, histidine and arginine, low recoveries were recorded. The recoveries of phenylalanine and leucine were similar to the PCV value. Regardless of the fractional 'recovery', all regression equations had gradients significantly different from zero.

For those AA not included in the infusate, values of mean transfers are presented and these can be compared with the pre-infusion values. Only for glutamine was there a substantial change, with a reduced extraction by the PDV in response to the AA infusion.

Hepatic removal. Under the basal conditions, the liver removed more than 0.9 of the absorbed alanine and glycine with substantial extraction also of serine and tyrosine (Table 3 ). In contrast, less than 0.5 of absorbed arginine and proline were extracted during passage 
D. WRAY-CAHEN $E T A L$.

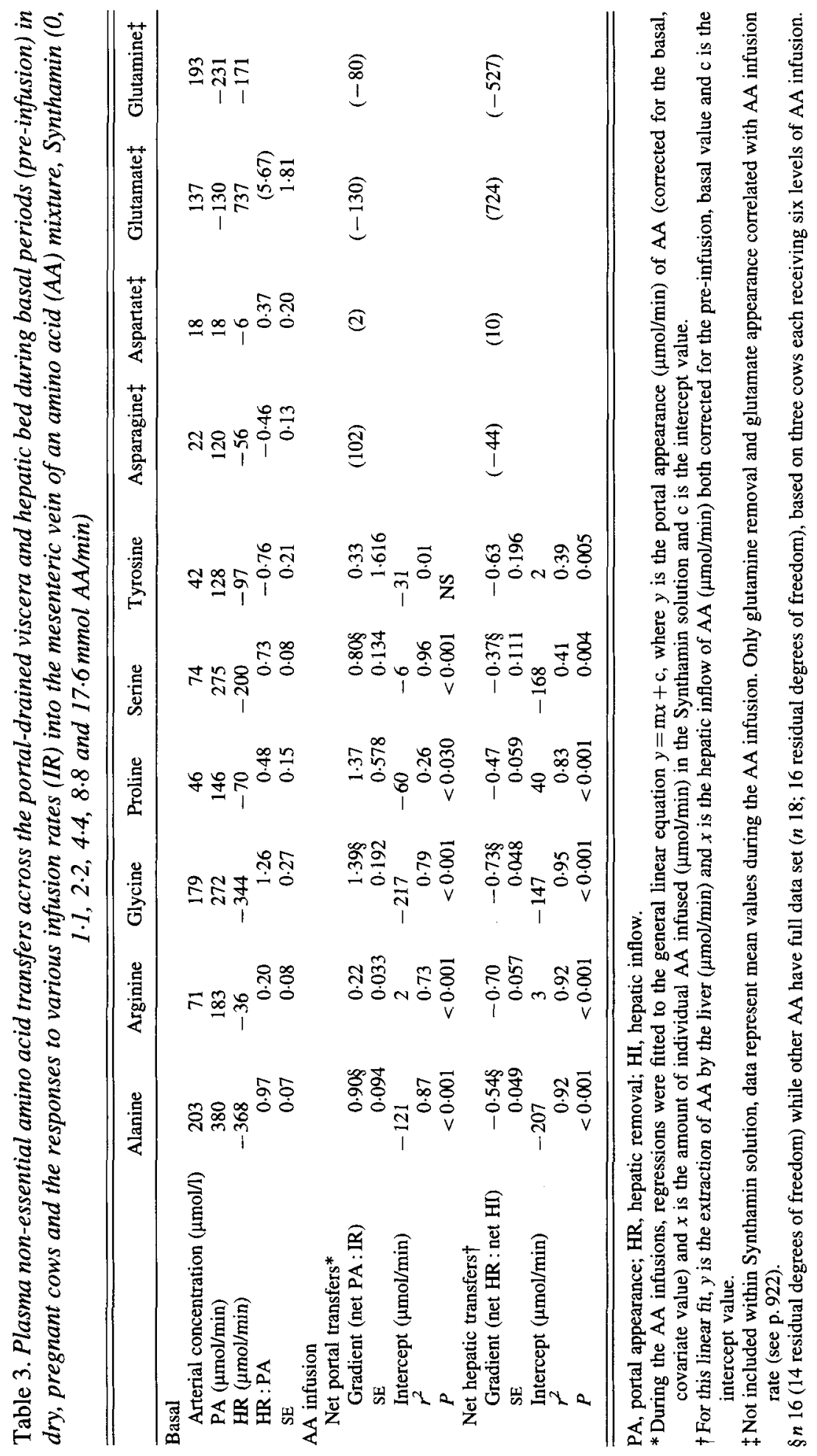




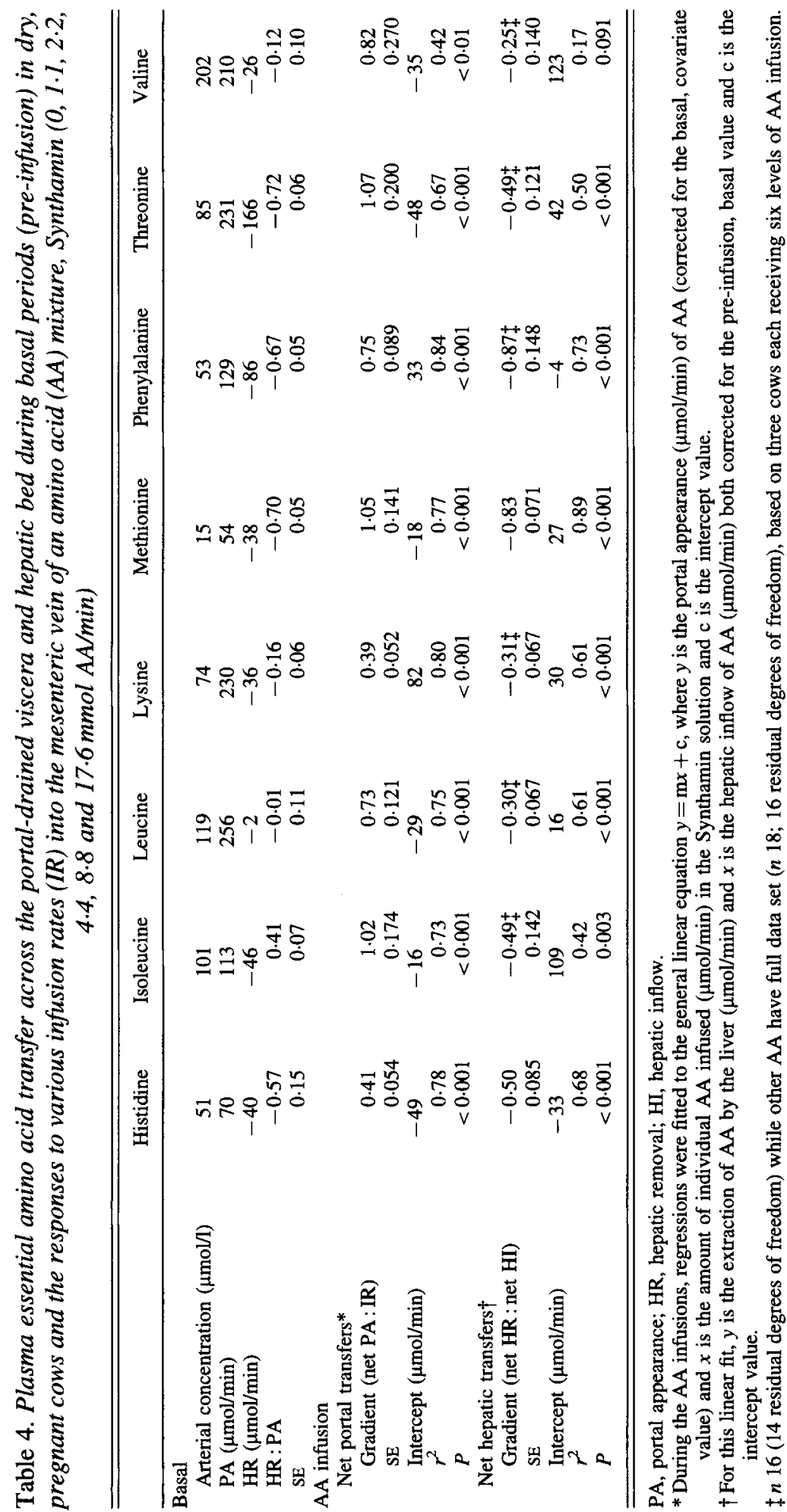


across the hepatic bed while there was net appearance of aspartate and, in particular, glutamate, the release of which exceeded the removal of glutamine (Table 3). For the essential AA the lowest proportional extractions were for the BCAA and lysine, with highest values for threonine, methionine and phenylalanine (Table 4).

None of the infused AA was completely extracted by the liver, as manifest by increases in arterial plasma concentrations (results not shown). In general, the data were more variable for hepatic removal than portal appearance, as might be expected from inclusion of another set of measurements (hepatic artery inflow and AA concentration). Strong linear regression equations were obtained for alanine, arginine, glycine and methionine (Tables 3 and 4). The other AA gave significant responses as both linear and quadratic functions but, with the exception of histidine, the linear equations were superior. For comparative purposes, the linear functions of histidine are presented in Table 4.

For all the NEAA the fractions of net hepatic inflow extracted during AA infusions were lower than for the pre-infusion period (dietary AA supply only), except for arginine which was increased and proline which was unchanged. The arginine comparisons may be confounded by low PDV appearance during the infusions, plus the problems related to the presence of arginase $(E C$ 3.5.3.1) in cattle blood (Covolo \& West, 1947). The fractional extractions ranged from -0.37 to -0.73 in the order serine $<$ proline $<$ alanine $<$ tyrosine $<$ arginine $<$ glycine. Of those not included within Synthamin there was a substantial elevation $(P<0.01)$ in glutamine removal by the liver in proportion to the rate of AA infusion ( $\mathrm{mmol} / \mathrm{min})$, i.e. $68 \mu \mathrm{mol} / \mathrm{min}\left(r^{2} 0.98, P<0.001\right)$ with a corresponding increase in glutamate output from the liver of $63 \mu \mathrm{mol} / \mathrm{min}\left(r^{2} 0.91\right.$, $P<0.04)$.

In contrast to the NEAA, the EAA had either maintained or increased fractional extractions compared with the pre-infusion periods, except for threonine. Removal of net hepatic inflow of phenylalanine and methionine exceeded 0.8 , with approximately 0.5 of histidine, threonine and isoleucine removed. The lowest extractions, -0.25 to -0.31 , were observed for valine, leucine and lysine.

\section{DISCUSSION}

\section{General considerations}

Although intra-mesenteric infusion of $\mathrm{AA}$ is an artificial situation compared with conventional feeding, it does reduce the number of variables that occur in response to food intake and which may confound metabolic interpretations. For example, additional metabolizable energy intake stimulates blood flow in a quantifiable manner (see Lindsay, 1993) but in the current study AA had no significant effect on either PDV or hepatic flows; thus the metabolic responses can be assessed against changes in concentration alone (see Hanigan et al. 1998). Furthermore, it would appear that the signals which lead to substantial changes in splanchnic blood flows are not associated with the quantities of AA presented to, or extracted by, the liver.

In this paper, the complete analysis of the AA data has been restricted to plasma exchanges, although comparisons for blood transfer of some AA will be reported elsewhere (Hanigan et al. 1998). Various studies have suggested that transport of absorbed AA to the liver occurs mainly within plasma (Elwyn et al. 1972; Houlier et al. 1991; Lobley et al. 1996) and the current observation that, for many of the AA, recovery of infused material in the hepatic portal venous plasma exceeded the proportion of plasma water: blood water would indicate that the erythrocytes are unlikely to be major carriers of absorbed AA. The situation with respect to hepatic mass transfers is more complex, with claims that the 
erythrocytes play a major role in transport from the liver to peripheral tissues (dogs, Elwyn et al. 1972; cattle, Houlier et al. 1991), although this has not been substantiated in other ruminant studies (sheep, Lobley et al. 1996). If the erythrocyte does play an important role, then this would lead to a decrease in the fractional extractions reported herein although, based on limited changes in free AA enrichments within erythrocytes during transit across the liver, evidence would suggest this is not a major concern in sheep (Lobley et al. 1996). It seems reasonable, in the light of such evidence, to assume that the bulk of splanchnic bed transport and exchange occurs through the plasma compartment.

In this study, analysis of the data has been based against the incremental appearances at the liver (i.e. net absorption) which is the traditional approach. In reality the liver receives total supplies from the hepatic portal vein plus hepatic arteries, which include AA recycled from endogenous and exogenous sources. An alternative approach based on the fractional removal of the total hepatic inflow is described in the companion paper (Hanigan et al. 1998).

\section{Amino acid transfers across the liver}

There are a limited number of reports in farm animals which detail removal of specific AA across the liver in the fed state (see Table 5). The earlier studies suffer from the drawback that, although the fraction of the absorbed AA removed by the liver may be substantial, this measurement is conducted against a large basal inflow from the arteries supplying the gastrointestinal tract. As an example, bovine arterial plasma contained glycine at $180 \mu \mathrm{mol} / \mathrm{l}$, under basal conditions, with total inflow to the liver of $4.6 \mathrm{mmol} / \mathrm{min}$, of which net hepatic removal accounted for approximately $5 \%$. For AA with lower fractional extractions the problem becomes more acute and concentration differences of only 2 $3 \%$ need to be determined. Such precision is at the limit of the best AA analyser systems and this leads to considerable variance and probably accounts for some of the differences between experiments, as illustrated in Table 5. The approach adopted here partially overcomes this difficulty by elevating the inflow of AA, under conditions where blood flow is unaltered; the increased concentration differences help to improve the analytical precision.

Two specific problems can be perceived with such an infusion approach. First, the rates of infusion may exceed normal physiological inputs and, second, competition between AA for transporters may result in lower extractions than is feasible if provision of only a single AA is augmented. The AA infusion at $8.8 \mathrm{mmol} / \mathrm{min}$, which was superimposed on a basal net absorption of approximately $2.5 \mathrm{mmol} / \mathrm{min}$, was calculated to provide similar quantities at the hepatic portal vein as for dairy cows consuming sufficient ration to produce $30 \mathrm{~kg}$ $\mathrm{milk} / \mathrm{d}$. Thus, the highest input of $17.6 \mathrm{mmol} / \mathrm{min}$ would be less than twice the expected physiological maximum achieved by nutritional means.

The second problem is more difficult to assess but infusion of a mixture of AA avoided imbalances which might occur from the use of a single AA and should better simulate the response to absorption from protein sources. The uptake of tyrosine, present in the infusate at low concentrations and which is transported by the L-system, in conjunction with phenylalanine and the BCAA, did exhibit a slightly reduced hepatic extraction, although this may be due to synthesis de novo from the added phenylalanine rather than an indication of metabolic competition for transporter activity. In contrast, although the fractional removal of alanine (transported primarily by the A and ASC systems which are shared by many other dipolar AA; Christensen, 1990) was less during the higher rates of infusion than for the basal periods, the value $(-0.57)$ was similar to the incremental 


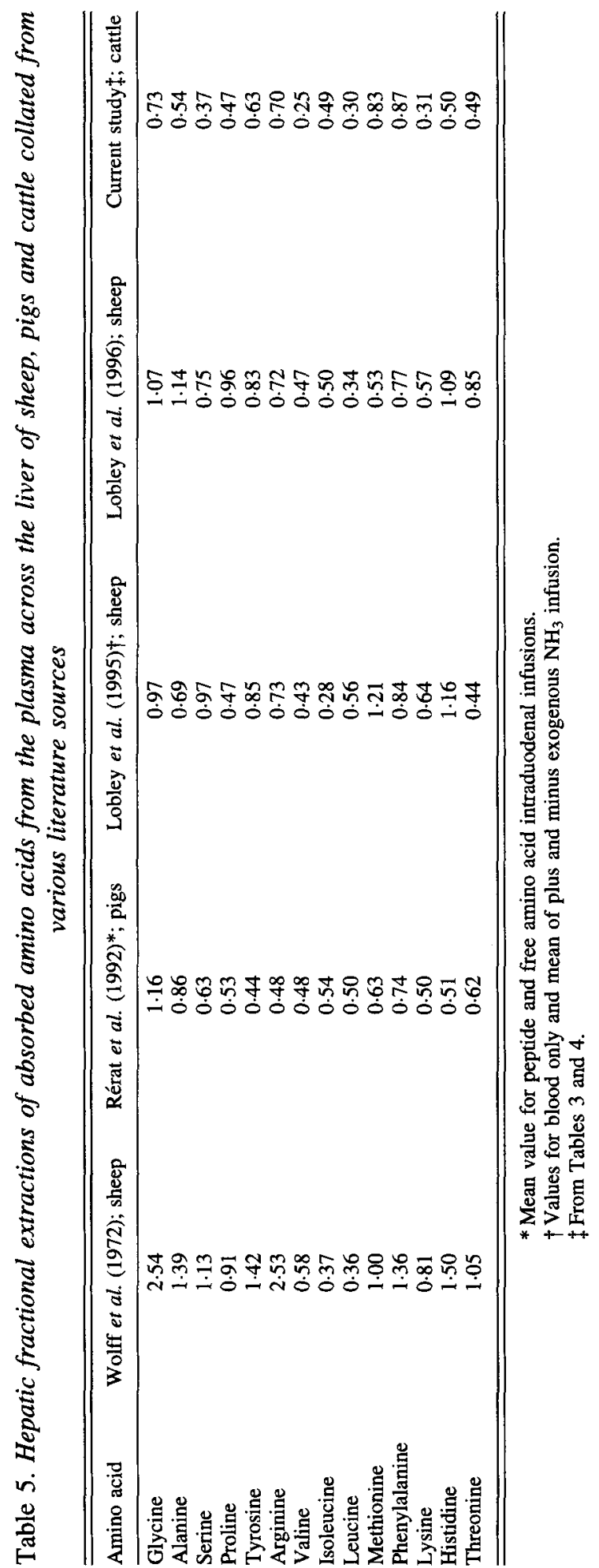


uptakes $(-0.59$ to -0.71$)$ observed by Reynolds \& Tyrrell (1991) when that AA alone was infused into non-pregnant heifers at $75 \mathrm{mmol} / \mathrm{h}$ (similar to the $4.4 \mathrm{mmol} / \mathrm{min}$ infusion of Synthamin used in the current study). Perhaps the strongest argument against transport competition comes from the data for phenylalanine, which shares the L-transporter with the BCAA and where extraction rates for all four AA during the infusions were similar to, or greater than, the basal period.

Overall, the amount of AA extracted by the liver is small compared with the total transporter capacity, e.g. in these animals liver mass was probably $10 \mathrm{~kg}$ and, at the highest rate of infusion, net hepatic threonine removal would approximate to $40 \mu \mathrm{mol} / \mathrm{min}$ per $\mathrm{kg}$ liver wet weight, less than $0.3 \%$ of the transport rate observed for isolated rat hepatocytes ( M. R. Hayes and J. D. McGivan, cited by McGivan, 1992). Extraction rates for other AA also appear low $(<1 \%)$ compared with values observed with hepatocytes isolated from rodents (McGivan et al. 1977). In terms of hepatic regulation in vivo of peripheral supply, the general linear response to increased AA inflow, under conditions which probably exceeded maximum physiological supply, would indicate that saturation of the uptake systems does not appear to occur. This was unequivocally so for alanine, arginine, glycine and methionine. This suggests two positive consequences; first, that the differences between fractions of absorbed AA removed are probably determined by metabolic reactions and fates within the liver rather than at the level of entry into the hepatocytes; and second, the fractional uptakes can be used in mathematical models designed to predict either tissue or whole body responses to variations in nutrient supply (see Hanigan $e t$ al. 1998).

\section{Metabolic fate of amino acids}

Absorbed AA have four potential fates: (1) retention in the free form as expanded pools in intra- and extravascular fluid; (2) conversion to specific nitrogenous metabolites (e.g. aromatic forms to neurotransmitters, glycine to hippurate, synthesis of di- and tripeptides such as carnosine, glutathione etc.); (3) oxidation to produce energy and non-nitrogenous intermediary metabolites; and (4) production of constitutive and export proteins. Estimation of the first two of these options is outwith the current investigation, but AA oxidation leads eventually to the synthesis of urea. Hepatic ureagenesis increased with rate of AA infusion (Table 1) and, if the apparent contribution from $\mathrm{NH}_{3}$ is subtracted, then the probable source of the remaining urea- $\mathrm{N}$ is $\mathrm{AA}$. One known requirement for $\mathrm{AA}$ in ruminants is to provide $C$ sources for gluconeogenesis, with alanine, glycine and glutamine (converted to glutamate within the periportal hepatocytes) as major precursors (Wolff \& Bergman, 1972). Indeed, if the hepatic uptake of these three AA is assumed to be directed totally to this fate, then this would provide, at the greatest rate of infusion, $5.8 \mathrm{mmol} / \mathrm{min}$ of three-C units, nearly enough to account for the extra $3 \mathrm{mmol} / \mathrm{min}$ of glucose produced. Similarly, the total $\mathrm{N}$ released from these three AAs would provide a major contribution to the increased ureagenesis (Fig. 1).

The situation with glutamine is of further interest in ureagenesis as two mechanisms exist within the ornithine cycle to ensure that the two $\mathrm{N}$ inputs $\left(\mathrm{NH}_{3}\right.$ to carbamoyl phosphate and aspartate to arginosuccinate) are maintained in balance. Thus, in situations of excess $\mathrm{NH}_{3}$ a proportion of the $\mathrm{N}$ can be diverted to mitochondrial aspartate (Cooper $e t$ al. 1987) via the actions of glutamate dehydrogenase (EC 1.4.1.2) and aspartate aminotransferase ( $E C$ 2.6.1.1). In contrast, when AA dominate absorption of $\mathrm{N}$ products then additional $\mathrm{NH}_{3}$ can be generated through mitochondrial glutaminase ( $E C$ 3.5.1.2) activity (Meijer et al. 1985). The progressive increase in hepatic uptake of glutamine, 


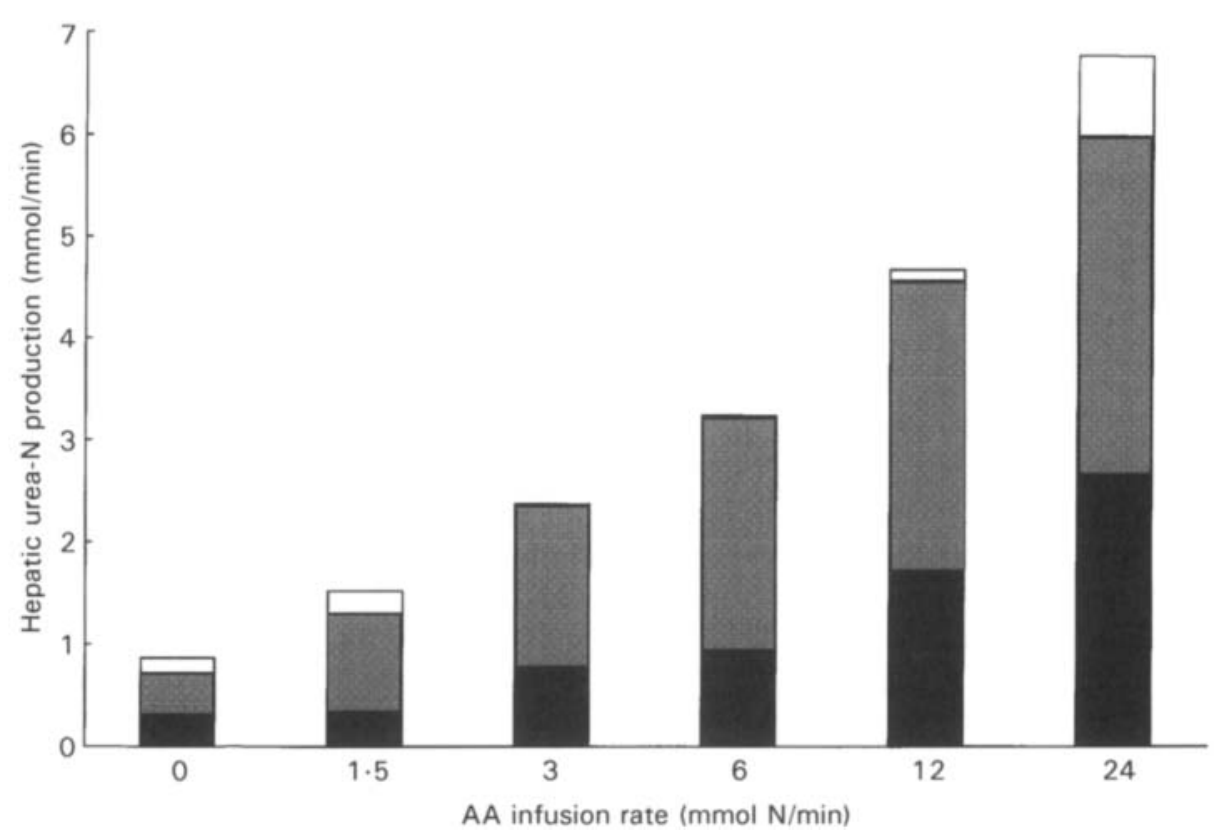

Fig. 1. Contribution of plasma alanine and glycine nitrogen $(\square)$ plus the amido-nitrogen of glutamine $(\square)$ to the extra hepatic urea-nitrogen produced in response to graded levels of amino acid (AA) nitrogen (as Synthamin) infused into the mesenteric vein. Differences between nitrogen uptake of the three AA and urea-nitrogen output are classified as 'unaccounted' ( $\square$ ).

which is available only from dietary or endogenous sources, with rate of AA infusion could, via amide- $\mathrm{N}$, contribute up to 0.17 of total $\mathrm{NH}_{3}$ entry into ureagenesis.

With the AA infusions, urea production failed to match either net inflow of AA or uptake by the liver so, presumably, the excess became available for additional hepatic and/ or peripheral tissue protein anabolism (Fig. 2). The amount available to net liver protein synthesis (of either a constitutive or export nature), including uptake of glutamine, rose progressively to $43 \%(10 \mathrm{mmol} A \mathrm{AA}-\mathrm{N} / \mathrm{min})$ of that infused. This increase in hepatic AA uptake could be due to stimulation of hepatic protein synthesis by either hyperaminoacidaemia (Tauveron et al. 1994) or hyperinsulinaemia (Mosoni et al. 1993; Davis et al. 1996). In sheep, hepatic synthesis of export proteins is sensitive to intake (Abbott et al. 1985; Connell et al. 1997) and if those data are scaled to the cow, serum albumin production may be increased from an estimated $35 \mathrm{~g} / \mathrm{d}$ to $60 \mathrm{~g} / \mathrm{d}$, or the equivalent of $0.2 \mathrm{mmol} \mathrm{AA}-\mathrm{N} / \mathrm{min}$. In addition, hepatic mass is sensitive to nutrition and can double over $21 \mathrm{~d}$ in sheep (Burrin et al. 1990) and, again if such observations can be extrapolated to cattle, then liver protein gain could equal $100 \mathrm{~g} / \mathrm{d}$, which would require an uptake of $0.8 \mathrm{mmol}$ AA-N/min. Even when combined, these values are still below the amount extracted by the liver and suggest that other fates are involved. Given the acute nature of this study, perhaps there was either expansion of the intracellular free AA pools, transient increases in 'storage' or 'reserve' liver proteins, an increase in the synthesis of export proteins other than albumin, and/or a suppression of liver proteolysis (Mortimore \& Surmacz, 1984).

The final considerations relate to the amount, pattern and fates of the AA which escape extraction by the liver. The total AA which entered the peripheral circulation reached a maximum of $11 \mathrm{mmol} \mathrm{N} / \mathrm{min}$ (Fig. 2), which gives an apparent 'protein' availability of 


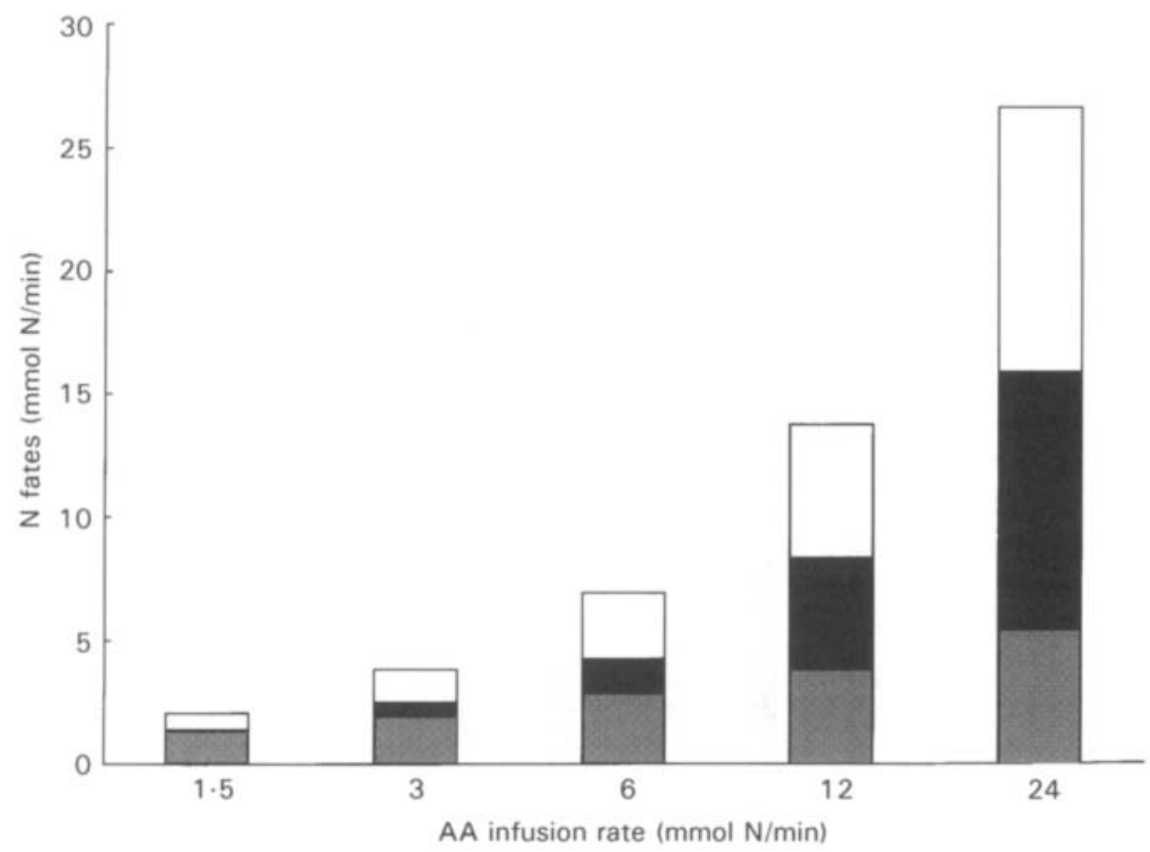

Fig. 2. Fates of amino acids (AA) allotted to either urea-nitrogen synthesis (W), protein synthesis (and other fates) within the liver ( $\square$ ) and available to peripheral tissues $(\square)$ in response to graded levels of AA-nitrogen (as Synthamin) infused into the mesenteric vein. Data based on plasma transfers and corrected for metabolite movements during infusion of saline (zero AA infusion rate).

$60 \mathrm{~g} / \mathrm{h}$. Such AA would be used for replenishment of muscle protein stores and support of uterine metabolism, including fetal growth. In late gestation cows, the requirements of the fetus and the total uterus have been estimated as 2 and $5 \mathrm{mmol}$ AA-N/min respectively (Bell, 1995). Data for rates of restoration of muscle mass are not available but these are probably substantially below the 'residual' $4 \mathrm{mmol} A A-\mathrm{N} / \mathrm{min}(80 \mathrm{~g} \mathrm{~N} / \mathrm{d})$. These considerations assume that the pattern of available AA is matched to the needs for tissue growth and fetal metabolism, but in practice, the AA entering the periphery are imbalanced and, for growing wethers, there is a theoretical anabolic limitation based on the relative availability of phenylalanine and histidine (Wolff et al. 1972; Lobley et al. 1995, 1996). In the current study the pattern of infused EAA which reached the peripheral circulation was also limited for phenylalanine supply, at least with respect to mixed muscle protein retention (Fig. 3), with subsequent restrictions in the order methionine, lysine $\cong$ threonine, while histidine and the BCAA were not limiting (excess of the latter can be oxidized by non-hepatic peripheral sources; Pell et al. 1986). Based on phenylalanine availability the potential net peripheral protein gain (muscle plus gestation components) decreases to $28 \mathrm{~g} / \mathrm{h}$, i.e. $5 \mathrm{mmol}$ AA-N/min, a value within the needs of the conceptus tissues and the capacity for transient expansion of other peripheral body protein stores, although the latter are difficult to quantify experimentally.

Of course, for all these AA any $\mathrm{N}$ not used for anabolic purposes in the peripheral tissues must eventually be converted to urea so the effects must be considered as temporary, including increased pool (vascular) sizes. The 'constant' fractional removal of AA by the liver (see also Hanigan et al. 1998) does allow sufficient of the absorbed 


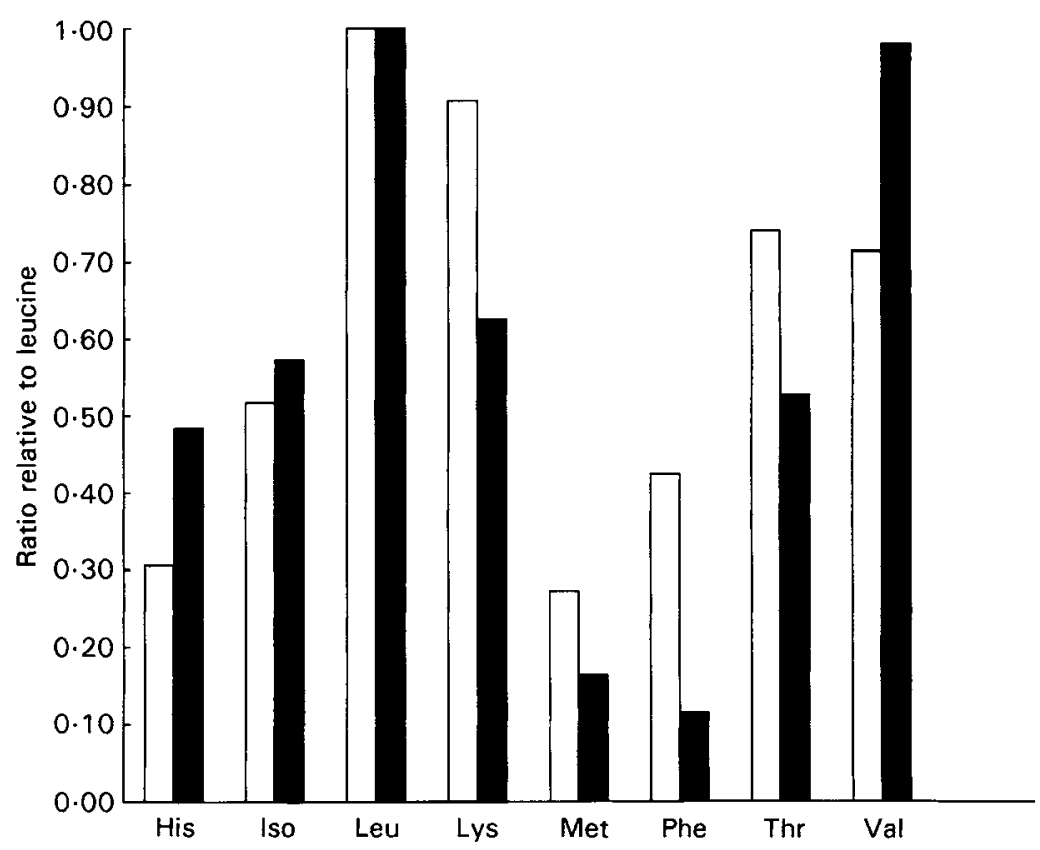

Fig. 3. The molar composition of amino acids (AA) ( $\mathbf{C}$ ), relative to leucine, which bypass the liver during infusions into the mesenteric vein of an AA mixture (Synthamin) in comparison with the molar AA composition ( $\square$ ), again relative to leucine, of ovine muscle protein. Data are corrected for AA movements during infusion of saline (zero AA infusion rate).

metabolites to reach the periphery and for mechanisms to operate (or be induced) to effect peripheral anabolism and a new homeorhetic condition.

The contribution of Dr C. K. Reynolds towards successful surgical preparations is gratefully acknowledged. The enthusiasm and expertise of Ms S. Roberts also contributed greatly to the success of this study. This study was funded as part of a collaborative project between the Ministry of Agriculture, Fisheries and Food, BP Nutrition (UK), the Milk Marketing Board of England and Wales, the Agricultural and Food Research Council and the Scottish Office Agriculture, Environment and Fisheries Department.

\section{REFERENCES}

Abbott, E. M., Parkins, J. J. \& Holmes, P. H. (1985). Influence of dietary protein on the pathophysiology of ovine haemonchosis in Finn Dorset and Scottish Blackface lambs given a single moderate infection. Research in Veterinary Science 38, 54-60.

Bell, A. W. (1995). Regulation of organic nutrient metabolism during transition from late pregnancy to early lactation. Journal of Animal Science 73, 2804-2819.

Bergman, E. N. (1973). Glucose metabolism in ruminants as related to hypoglycemia and ketosis. Cornell Veterinarian 63, 341-382.

Brier, B. H., Gallagher, B. W. \& Gluckman, P. D. (1991). Radioimmunoassay for insulin-like growth factor-1: solutions to some potential problems and pitfalls. Journal of Endocrinology 128, 347-357.

Burrin, D. G., Ferrell, C. L., Britton, R. A. \& Bauer, M. (1990). Level of nutrition and visceral organ size and metabolic activity in sheep. British Journal of Nutrition 64, 439-448.

Christensen, H. N. (1990). Role of amino acid transport and countertransport in nutrition and metabolism. Physiological Reviews 70, 43-77.

Connell, A., Calder, A. G., Anderson, S. E. \& Lobley, G. E. (1997). Hepatic protein synthesis in the sheep: effect of intake as monitored by use of stable-isotope-labelled glycine, leucine and phenylalanine. British Journal of Nutrition 77, 255-271. 
Cooper, A. J. L., Nieves, E., Coleman, A. E., Filc-De Ricco, S. \& Gelbard, A. S. (1987). Short-term metabolic fate of $\left[{ }^{13} \mathrm{~N}\right]$ ammonia in rat liver in vivo. Journal of Biological Chemistry 262, 1073-1080.

Covolo, G. C. \& West, R. (1947). The activity of arginase in red blood cells. Journal of Clinical Endocrinology 7, 325-330.

Davis, T. D., Burrin, D. G., Fiorotto, M. L. \& Nguyen, H. V. (1996). Protein synthesis in skeletal muscle and jejunum is more responsive to feeding in 7- than in 26-day-old pigs. American Journal of Physiology 270 , E802-E809.

Elwyn, D. H., Launder, W. J., Parikh, H. C. \& Wise, E. M. Jr (1972). Roles of plasma and erythrocytes in interorgan transport of amino acids in dogs. American Journal of Physiology 222, 1333-1342.

Hanigan, M. D., France, J., Wray-Cahen, D., Beever, D. E., Lobley, G. E., Reutzel, L. \& Smith, N. E. (1998). Alternative models for analyses of liver and mammary transorgan metabolite extraction data. British Journal of Nutrition 79 (In the Press).

Houlier, M. L., Patureau-Mirand, P., Durand, D., Bauchart, D., Lefaivre, J. \& Bayle, A. (1991). Transport des acides amines dans l'aire splanchnic par le plasma sanguin et le sang chez le veau préruminant (Transport of amino acids in blood and plasma across the splanchnic region of preruminant calves). Reproduction, Nutrition and Development 31, 399-410.

Huntington, G. B., Reynolds, C. K. \& Stroud, B. H. (1989). Techniques for measuring blood flow in splanchnic tissues of cattle. Journal of Dairy Science 72, 1583-1595.

Lindsay, D. B. (1993). Metabolism of the portal-drained viscera. In Quantitative Aspects of Ruminant Digestion and Metabolism, pp. 267-289 [J. M. Forbes and J. France, editors]. Wallingford: CAB INTERNATIONAL.

Lobley, G. E., Connell, A., Lomax, M. A., Brown, D. S., Milne, E., Calder, A. G. \& Farningham, D. A. H. (1995). Hepatic detoxification of ammonia in the ovine liver; possible consequences for AA catabolism. British Journal of Nutrition 73, 667-685.

Lobley, G. E., Connell, A., Revell, D. K., Bequette, B. J., Brown, D. S. \& Calder, A. G. (1996). Splanchnic-bed transfers of amino acids in sheep blood and plasma, as monitored through use of a multiple U- ${ }^{13} \mathrm{C}$-labelled amino acid mixture. British Journal of Nutrition 75, 217-235.

McGivan, J. D. (1992). Techniques used in the study of plasma membrane amino acid transport. In Mammalian Amino Acid Transport; Mechanisms and Control, pp. 51-63 [M. S. Kilberg and D. Haussinger, editors]. New York: Plenum Press.

McGivan, J. D., Bradford, N. \& Merdes-Mourao, J. (1977). The transport of branched-chain amino acids into isolated rat liver cells. FEBS Letters 80, 380-394.

Meijer, A. J., Lof, C., Ramos, I. C. \& Verhoeven, A. J. (1985). Control of ureagenesis. European Journal of Biochemistry 148, 189-196.

Metcalf, J. A., Beever, D. E., Sutton, J. D., Wray-Cahen, D., Evans, R. T., Humphries, D. J., Backwell, F. R. C., Bequette, B. J. \& MacRae, J. C. (1994). The effect of supplementary protein on in vivo metabolism of the mammary gland in lactating dairy cows. Journal of Dairy Science 77, 1816-1827.

Mortimore, G. E. \& Surmacz, C. A. (1984). Liver perfusion: an in vitro technique for the study of intracellular protein turnover and its regulation in vivo. Proceedings of the Nutrition Society 43, 161-167.

Mosoni, L., Houlier, M.-L., Mirand, P. P., Bayle, G. \& Grizard, J. (1993). Effect of amino acids alone or with insulin on muscle and liver protein synthesis in adult and old rats. American Journal of Physiology 264, E614 E620.

Pell, J. M., Calderone, E. M. \& Bergman, E. N. (1986). Leucine and $\alpha$-ketoisocaproate metabolism and interconversions in fed and fasted sheep. Metabolism 35, 1005-1016.

Rérat, A., Simoes-Nuñes, C., Mendy, F., Vaissade, P. \& Vaugelade, P. (1992). Splanchnic fluxes of amino acids after duodenal infusion of carbohydrate solutions containing free amino acids or oligopeptides in the nonanaesthetized pig. British Journal of Nutrition 68, 111-138.

Reynolds, C. K. \& Tyrrell, H. F. (1991). Effects of mesenteric vein L-alanine infusion on liver metabolism in beef heifers fed on diets differing in forage:concentrate ratio. British Journal of Nutrition 66, 437-450.

Seal, C. J., Parker, D. S. \& Avery, P. J. (1992). The effect of forage and forage-concentrate diets on rumen fermentation and metabolism of nutrients by the mesenteric- and portal-drained viscera in growing steers. British Journal of Nutrition 67, 355-370.

Sigaard-Anderson, O. (1974). The Acid-Base Status of Blood, 4th revised ed., p. 22. Copenhagen: Munksgaard.

Symonds, M. E., Bryant, M. J. \& Lomax, M. A. (1986). The effect of shearing on the energy metabolism of the pregnant ewe. British Journal of Nutrition 56, 635-643.

Tauveron, I., Larbaud, D., Champredon, C., Debras, E., Tesseraud, S., Bayle, G., Bonnet, Y., Thieblot, P. \& Grizard, J. (1994). Effect of hyperinsulinemia and hyperaminoacidemia on muscle and liver protein synthesis in lactating goats. American Journal of Physiology 267, E877-E885.

Tindall, J. S., Knaggs, G. S., Hart, I. C. \& Blake, L. A. (1978). Release of growth hormone in lactating and nonlactating goats in relation to behaviour, stages of sleep, electroencephalograms, environmental stimuli and levels of prolactin, insulin, glucose and free fatty acids in the circulation. Journal of Endocrinology 76, 333346. 
Wolff, J. E. \& Bergman, E. N. (1972). Metabolism and interconversions of five plasma amino acids by tissues of the sheep. American Journal of Physiology 223, 447-454.

Wolff, J. E., Bergman, E. N. \& Williams, H. H. (1972). Net metabolism of plasma amino acids by liver and portal-drained viscera of fed sheep. American Journal of Physiology 223, 438-446. 